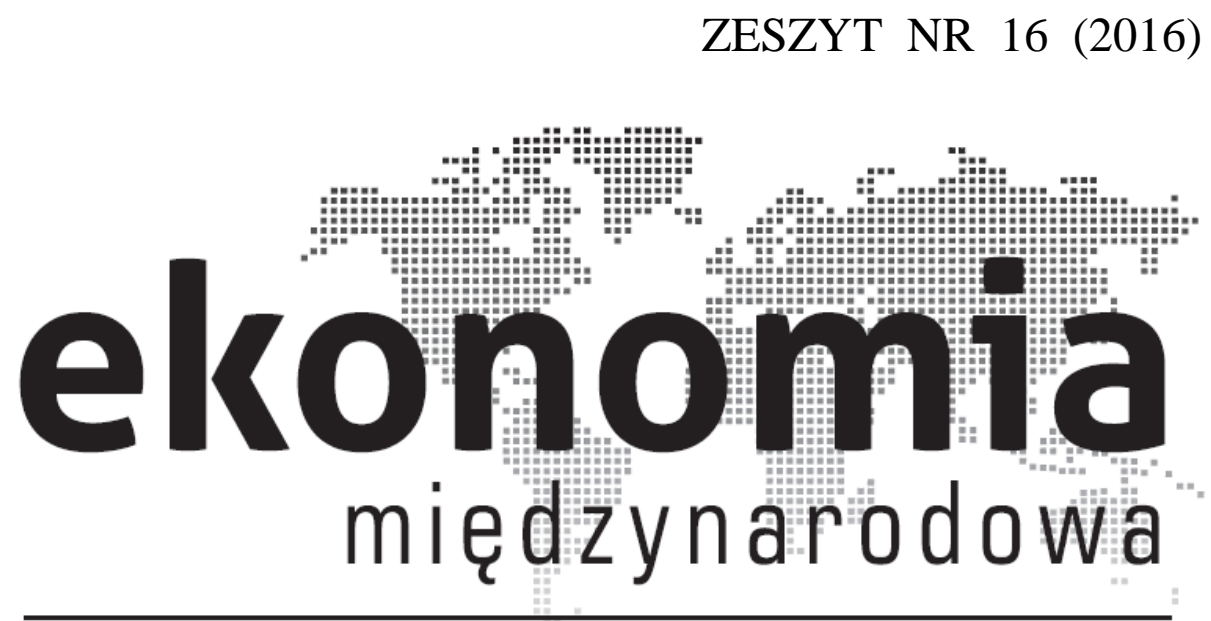

Ekonomia Międzynarodowa

Nr 16 (2016)

www.ekonomia-m.pl

ISSN: 2082-4440

EISSN: 2300-6005

Wydawca: Uniwersytet Łódzki

Wersja elektroniczna czasopisma jest wersją referencyjną
Publisher: University of Lodz

Electronic edition is the reference version of the journal
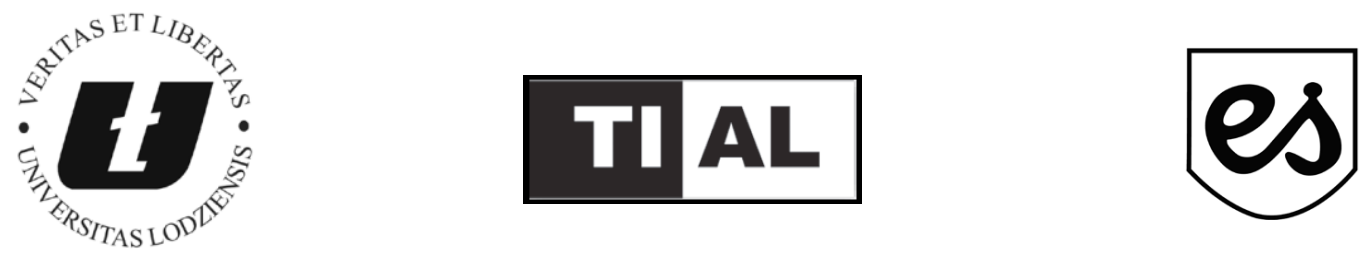


\title{
An Assessment of Islamic Banking in Bosnia and Herzegovina - a comparative analysis using the CAMELS approach
}

\author{
Rafał Komorowski* \\ Katarzyna Kubiszewska**
}

\section{Introduction}

Islamic finance, including Islamic banking, is one of the sectors of financial systems which have undergone a significant change. It is recognized as an alternative for clients to perform financial operations in many countries all over the world, not only in places where the Islamic population is in the majority. Islamic banking has been present in Europe for over three decades.

The aim of the article is to conduct a comparative analysis - using the CAMELS approach - of the financial standing of one purely Islamic bank in Bosnia and Herzegovina, the whole banking sector in that country, and the banking sectors in the region of the Western Balkans; and to verify the hypothesis that Bosna Bank International's financial situation is more stable as aresult of its adopted business model.

The article has been divided into three parts. The first part addresses the problem of comparing Islamic banking to conventional banking, as laid out in the literature on the subject. The second part describes the potential for developing Islamic finance in Bosnia and Herzegovina, while the last part presents the results of the financial analysis conducted with the use of CAMELS. It also verifies the proposed hypothesis by comparing selected financial indicators.

\footnotetext{
* Rafał Komorwski - M.Sc., Gdańsk University of Technology, Faculty of Management and Economics, Department of Economic Analysis and Finance.

** Katarzyna Kubiszewska - PhD, Gdańsk University of Technology, Faculty of Management and Economics, Department of Economic Analysis and Finance.
} 


\section{Islamic versus conventional banking - a comparison of the two banking models in the literature}

The theoretical literature points out various differences between Islamic and conventional banking. The crucial point of difference is the profit-and-loss sharing paradigm (PLS) that encapsulates the concept of Islamic contracting: profit-sharing (mudarabah) and joint venture (musyarakahik), since the charging of interest (riba) is not allowed in Islam. This means that borrowers need to share profits and losses with banks, which in turn are obliged to share profits and losses with depositors (Khan, Mirakhor, 1989, pp. 39-57; Iqbal, 2001, pp. 1-28). The literature on the topic addresses two crucial matters related to the PLS paradigm: Islamic banking should be able to absorb external shocks because the risk is shared equally by both sides of a transaction, and the potential for longer-term lending with higher risk-return profiles ought to contribute to economic growth (Chapra, 1992; Mills, Presley, 1999).

The conducted studies can be placed into two categories. In spite of the theoretical differences between Islamic banking (IB) and conventional banking (CB), in practice both banking solutions show very similar business models. Studies aimed at checking the range of similarities and differences between IB and CB were conducted by Chong and Liu (2009), Johnes et.al (2014), Ashfaq et.al (2010) Beck, Demirgüç-Kunt and Merrouche (2013) and by Bourkhis and Nabi (2013). All of them proved that IB is not very different from CB. Chong and Liu (2009, pp. 125-144) investigated the PLS paradigm. Johnes et al. (2014, p. 104) compared the banking sectors' efficiency between 2004 and 2009 and concluded that there were no significant differences in gross efficiency (on average) between the two models of banking. The same issue was examined by Shamsher et al. (2007, pp. 107-130) who suggested that there were no significant differences between the overall efficiency results of conventional versus Islamic banks. Beck et al. (2013, p. 445) extended the previous studies by also considering risk-taking and stability; and the study results remained in line with those previously mentioned.

Bourkhis and Nabi (2013, p. 75) examined the effect of the 2007-2008 financial crisis on the soundness of Islamic banks and their conventional counterparts. The results showed that there was no significant difference between IBs and CBs in terms of the effect of the financial crisis on banking soundness. Ashfaq et al. (2010, p. 141) proved the lack of difference between both models by analyzing the relationship between service quality and customer satisfaction. In both cases, a strong positive relationship was found. Performance was also an area of study for Siti et al. (2011, pp. 199-207). The authors found no major difference in financial performance between IB and CB, except in terms of liquidity. This indicated that IB is generally more liquid than conventional banking.

On the other hand, there are advocates for the advantages of one of the studied banking models. Iqbal (2001, p. 26) found that, in general, IB has done fairly 
well where performance is concerned. There are also studies showing that while there was no noteworthy difference in profitability between both models, IB turned out to be relatively more liquid and less risky than CB (Hamid, Azmi, 2011, pp. 09-19). Liquidity was the subject of studies conducted by Usman and Khan (2012, pp. 253-257) who showed that Islamic banks not only had a high growth rate and profitability, but also higher liquidity power than conventional ones. A very similar conclusion can be found in Olson et al.'s (2008, p. 62) study that showed that Islamic banks are more profitable, but probably not quite as efficient.

Awan (2009, pp.1-36) and later Safiullah (2010, p. 199, 203) proved that the performance of interest-free Islamic banks in business development, profitability, liquidity, and solvency was superior to that of interest-based conventional banks. Islamic banks outperformed conventional banks in terms of assets, deposits, financing, investments, efficiency, quality of service, and loan recovery. Hasan and Dridi (2010, pp. 33-34) obtained similar results for Islamic banking in 2008-09, which demonstrated that IB contributed to financial and economic stability.

Moin (2008, p. 38), however, obtained the opposite results after comparing the first Islamic bank in Pakistan with a group of conventional banks. The conventional banks presented more favourable results in terms of profitability, risk, and efficiency for the period of 2003-2007, but there was no significant difference in liquidity between the two sets of banks. Ariss (2010, p. 107) studied competitive conditions and indicated that the global Islamic banking market exhibits more concentration and less competition than the conventional banking market.

Manshor et al. (2011, pp. 822-841) revealed that there were large and significant differences between respondents' expectations and their perceptions of these two types of banking, specifically in terms of their competence and convenience. Sudin et al. (2008, pp. 618-643) when comparing the behavior of customers of the two banking models, found that, in most cases, customers of the conventional system behaved in conformity with savings behavior theories, while most of these theories were not applicable to Islamic banking customers. Therefore, there is a possibility that religious belief plays an important role in the banking decisions of Muslim customers.

Cevik and Charap (2011, pp. 10-21) showed in their analysis that conventional bank deposit rates and PLS returns exhibit long-run cointegration, and that the time varying volatility of conventional bank deposit rates and PLS returns correlates and is statistically significant. The pairwise and multivariate Granger causality tests show that conventional bank deposit rates cause returns on PLS accounts. These findings suggest that conventional banking leads in terms of profitability and liquidity, while Islamic banking dominates in terms of credit risk management and solvency maintenance. The motivating factors for customers of Islamic banking are location and Sharia compliance, while for conventional banking it is the wide range of products and services. 


\section{The potential development of Islamic finance in Bosnia and Herzegovina}

\section{The Islamic business model in Bosnia and Herzegovina}

When researching Islamic finance, it is not difficult to observe that its level of development varies between regions. It is strongly influenced by microeconomic and macroeconomic factors and can take on various forms in a particular region or country (Warde, 2000). The following proposed classification distinguishes four market groups based on the number of Islamic Financial Institutions (IFI) and the size of the Islamic capital in a region or country:

1) IB is the main stream (Malaysia, Iran, Saudi Arabia);

2) IB's presence is a niche (Egypt, Jordan, Syria, Latin America, Great Britain);

3) Governments and regulators cooperate with Islamic Banks but their presence cannot be significantly observed (USA, India);

4) IB is in the early exploration phase (Bulgaria, Somalia).

Table 1 illustrates the Islamic capital distribution across different regions. Its biggest concentration can be observed in the Middle East and North Africa (MENA) and Gulf Cooperation Council (GCC) regions where Islamic Finance has become mainstream, while the largest share of assets in the "others" group belongs to the United Kingdom, which is a European hub for Islamic Finance (Komorowski, Kubiszewska 2014).

Table 1. Distribution of Islamic assets by region 2013 (million USD)

\begin{tabular}{|l|c|c|c|c|}
\hline Assets by Region & Banking Assets & $\begin{array}{c}\text { Sukuk } \\
\text { (Islamic Bonds) } \\
\text { Outstanding }\end{array}$ & $\begin{array}{c}\text { Islamic } \\
\text { Fund Assets }\end{array}$ & $\begin{array}{c}\text { Takaful } \\
\text { (Islamic } \\
\text { insurance) } \\
\text { Contributions }\end{array}$ \\
\hline Asia & 171.8 & 160.3 & 22.6 & 2.7 \\
\hline GCC & 434.5 & 66.3 & 28.9 & 7.2 \\
\hline MENA (excl. GCC) & 590.6 & 1.7 & 0.2 & 6.9 \\
\hline Sub-Saharan Africa & 16.9 & 0.1 & 1.6 & 0.4 \\
\hline Others & 59.8 & 1.0 & 10.8 & 0.0 \\
\hline Total USD & 1273.6 & 229.4 & 64.2 & 17.2 \\
\hline \% of Total & 80.4 & 14.5 & 4.1 & 1.0 \\
\hline
\end{tabular}

Source: (A.T. Kearney Korea LLC, 2012).

At first glance, it may be easily observed which countries have the biggest IB sector. However, it is important to be aware that they also vary in terms of the size of the Muslim population, the mainstream religion, the government's policies towards IB, and many other factors which affect this sector. 
There are many different methods that may be used to assess the level of a banking sector's development within a country. These would include traditional measures like the size and depth of the banking system where time series data would be used (Arestis, Panicos 1997); and modern measures which examine the efficiency and stability of the entire sector, similar to the use of CAMELS in this paper (Cargill, 1989). To measure the very specific and small Islamic Banking sector in Bosnia and Herzegovina $(\mathrm{B} \& \mathrm{H})$, it is good to start with the very simple equation introduced in Formula 1.

Formula 1. IFI Saturation Index

$\mathrm{SI}=\mathrm{n} / \mathrm{p}$

SI - Islamic Financial Institution Saturation Index

$\mathrm{n}$ - total number of Islamic financial institutions in the country

$\mathrm{p}-$ total population of thecountry

This very simple calculation provides a good first look at the development of Islamic Finance in these countries. For the purpose of this study, the IFI saturation has been calculated in Table 2 for B\&H as well as for other states which play or could play an important role in the development of IB. The second important factor is the number of IFI divided by the Muslim population - this provides information about the Islamic contract availability for a specific group of people who are prospective users of such services. Besides calculating the SI factor, the authors have also provided additional data (IFI count, total population, Muslim population with its share and GDP per capita). Additional data has been presented in the table to indicate key differences between the countries.

Table 2. Number of Islamic Financial Institutions per country's population 2012

\begin{tabular}{|c|c|c|c|c|c|c|c|}
\hline Country & 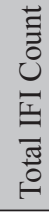 & 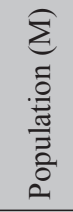 & 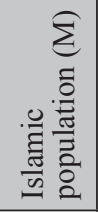 & 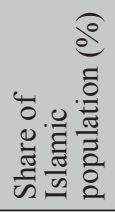 & 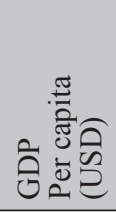 & 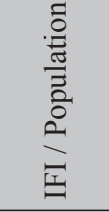 & 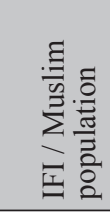 \\
\hline Germany & 3 & 82.0 & 4.1 & 5.0 & 32.800 & 0.0366 & 0.7317 \\
\hline France & 4 & 65.0 & 4.7 & 7.5 & 31.200 & 0.0615 & 0.8511 \\
\hline United Kingdom & 13 & 63.7 & 2.9 & 4.6 & 29.400 & 0.2041 & 4.4828 \\
\hline Bosnia and Hertzegovina & 1 & 3.8 & 1.7 & 45.0 & 9.356 & 0.2632 & 0.5882 \\
\hline Iran & 54 & 75.0 & 74.8 & 99.7 & 13.300 & 0.7200 & 0.7219 \\
\hline Saudi Arabia & 99 & 27.0 & 25.5 & 97.1 & 26.200 & 3.6667 & 3.8824 \\
\hline United Arab Emirates & 73 & 7.5 & 3.6 & 76.0 & 29.900 & 9.7333 & 20.2778 \\
\hline
\end{tabular}

Source: (Thomson Reuters Zawya, 2015). 
The data presented in Table 2 has to be analyzed with caution because, in addition to differences in measures, the countries are very diverse in other ways. This means that the quantitative data could have a different meaning in each case. At first glance, it is easy to observe that the United Arab Emirates (UAE) has a market fully penetrated by IFIs. Both penetration factors show high values, which makes the UAE the undisputed leader in terms of IFI services availability. The very large number of IFIs in the UAE is due to its international trade driven by the commodity exchange (oil) and its overhead services. Also, it is important to note the Emirates' high GPD per capita in comparison withother countries in the Gulf region (Bley, Kuehn, 2004).

Both factors for Iran are surprisingly low; however, this might be due to Iran's low GPD per capita and long term isolation from international trade (Torbat, 2005), which has affected Iran's entire banking sector. At the same time, Iran is a country with strict Sharia rules and with almost no conventional banking sector. This means that strong commercial relations can greatly influence the development of IFIs. For B\&H, market penetration indicators are at an almost similar level to those of Iran, but in Iran this affects $99.7 \%$ of the society, while in B\&H it affects much less (45\%). If it is assumed that the non-Muslim part of B\&H's society would be interested in this type of service, then we could observe a significant opportunity for further development of IB in B\&H. In addition, the indicators are slightly higher in France and Germany than in B\&H; however, this affects a smaller percentage of the society, so they would potentially have a better outlook on IB development than B\&H does.

The United Kingdom takes the lead in Islamic finance services availability (UK Trade \& Investment 2014). With its relatively small Muslim population, it provides a very good availability of IFIs spread across the entire country, while three remaining European countries - France, Germany and Bosnia and Herzegovina - demonstrate rather low penetration rates, as illustrated in Table 2. Despite the larger number of IFIs present in Germany and France, only Bosnia and Herzegovina has a fully-fledged Islamic bank where products are officially certified by a Sharia Board; this has a significant meaning to retail customers who are willing to invest in a product certified by a Sharia board rather than take the risk of investing in a contract without that certification.

Thanks to the UK's success in Islamic finance framework implementation, it is now easy to determine some key success factors that could influence the sector's development:

1) being the world's number two financial center;

2) the undertaken legal changes to eliminate barriers for IB;

3) the significant size of the Muslim population;

4) the good economic conditions;

5) the very strong relationships with GCC countries. 
Figure 1 illustrates the most common success factors that contribute to a country's success in developing a significant Islamic finance market.

Figure 1. Success factors of Islamic finance development

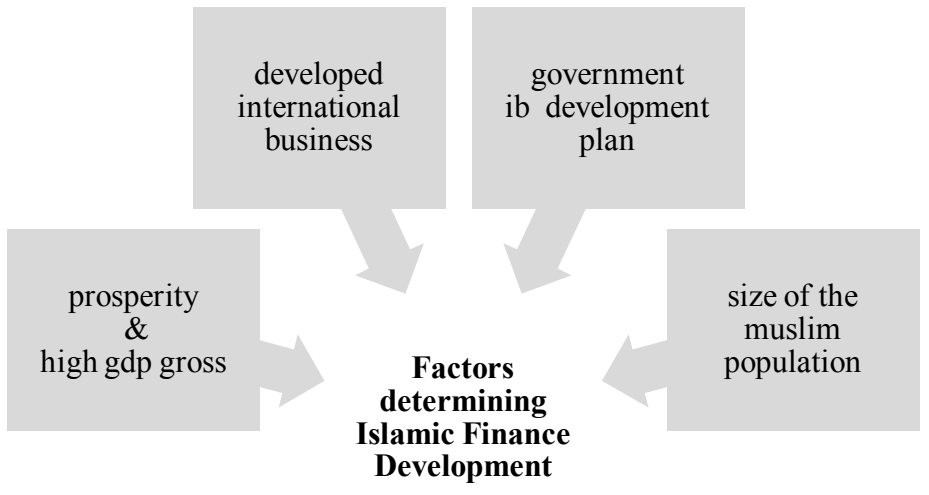

Source: author's own elaboration

Bosnia and Herzegovina is the only European state with a Muslim majority. It is a country with a population of 3.8 million and $\$ 9,356$ GDP per capita in 2012, which positions this country low in comparison to other European states mentioned in Table 2 (The World Bank, 2015). However, Bosnia and Herzegovina, due to the significant size of its Muslim population (1.7 million, $45 \%$ of the total) and its one fully fledged Islamic bank (Bosna Bank International d.d. Sarajevo (BBI)), is the second country which could play an important role in Islamic finance development in Europe. Based on the analyzed success factors for the development of IB, B\&H does not look like a very promising candidate. An assessment of whether selected countries meet the criteria for success in this area has been illustrated in Table 3.

Table 3. Success factors of Islamic finance development in selected countries

\begin{tabular}{|l|l|l|l|c|}
\hline Success factor level / Country & B\&H & UK & Germany & France \\
\hline $\begin{array}{l}\text { Prosperity \& High GDP Gross } \\
\begin{array}{l}\text { Annual and current GDP growth } \\
\text { (A) - annual, (C) - current }\end{array}\end{array}$ & $\begin{array}{l}4.4(\mathrm{~A}) \\
0.7(\mathrm{C})\end{array}$ & $\begin{array}{c}2.30(\mathrm{~A}) \\
0.5(\mathrm{C})\end{array}$ & $\begin{array}{c}1.60(\mathrm{~A}) \\
0.4(\mathrm{C})\end{array}$ & $\begin{array}{c}1.08(\mathrm{~A}) \\
0(\mathrm{C})\end{array}$ \\
\hline $\begin{array}{l}\text { Developed International Business } \\
\text { Export size / Place among the } \\
\text { world's exporters }\end{array}$ & $\$ 564 \mathrm{~B} / 111$ & $\$ 453 \mathrm{~B} / 11$ & $\$ 138 \mathrm{~T} / 3$ & $\$ 564 \mathrm{~B} / 7$ \\
\hline $\begin{array}{l}\text { Government IB Development Plan } \\
\text { Actions undertaken by the } \\
\text { government }\end{array}$ & $\begin{array}{c}\text { Early } \\
\text { explorations }\end{array}$ & Implemented & $\begin{array}{c}\text { Does } \\
\text { not exist }\end{array}$ & $\begin{array}{c}\text { not exist } \\
\text { Does }\end{array}$ \\
\hline Share of Muslim Population & $45 \%$ & $4.60 \%$ & $5 \%$ & $7.5 \%$ \\
\hline
\end{tabular}

Source: (Observatory of Economic Complexity, 2015), (Trading Economics, 2015). 
Table 3 indicates that $\mathrm{B} \& \mathrm{H}$ has the largest number of Muslim citizens among all of the compared European states. It also has a very high GPD growth rate, which indicates that this is an emerging country. This means that out of four success criteria defined in Figure 1, B\&H meets two of them: GDP gross and a significant sizeof Islamic population. The Islamic finance sector has not yet developed in this country mainly because of the lack of government plans to enhance these types of services. Initially, the government started some early explorations into this topic, and in May 2010 the Prime Minister, the Minister of Finance, and the Central Bank Governor participated in the Islamic finance seminar. The government decided not to take very aggressive steps to implement Islamic finance as it is related to Sharia rules towards finance, which might cause anxiety for the non-Muslim part of the society (IFN Islamic Finance News, 2014). This is the most probable reason that the government has not undertaken any serious steps towards implementing IB. Even the Islamic bank in B\&H - Bosna Bank International had problems with obtaining its banking license due to the negative perception of the country's non-Muslim society (Zulkifli, 2010). Also, the country's relatively small economy and legal and financial constraints are preventing this sector from further development.

The Muslim part of society is much smaller than in France or Germany, but it is larger than in Great Britain. However, the Muslim part of society in Britain is much wealthier than that in $\mathrm{B} \& \mathrm{H}$. This means that despite the large number of Muslims, the prospective Islamic finance market would be smaller than in the UK.

Further development of Islamic Finance in B\&H remains under a question mark. On the one hand, there is a good customer base and enough economic growth to develop this type of service, but the government's lack of interest will definitely not encourage investors from the Gulf Cooperation Council (GCC) members. In addition, very poor infrastructure in the region discourages investors.

\section{The general situation in the banking sector}

The last decade of the $20^{\text {th }}$ century is recognized as a weak period in the transformation of the banking sector in B\&H. Only the introduction of market reforms which liberalized the entrance of foreign direct investment acted as a starting point for further banking reforms (Babić-Hodović, Tesche, 2006, pp. 1-7). The transformation of the banking sector led to the current situation in which the market is governed both by a supervision agency and by banking laws (CBBH Financial Stability Report, 2010).

The financial sector in B\&H is comprised of commercial banks, credit organizations, leasing companies, investment funds, and insurance companies; commercial banks' share of the total assets has reached $84 \%$, meaning that the dominant part of the financial sector is created by the banking market (Casu et al., 2006, p. 4). The positive relationship between financial sector developments and economic growth 
has been proved in other empirical studies (e.g. Alfaro et al., 2003, pp. 1-33; Babić-Hodović et al., 2009, pp. 683-693). The number of banks has been decreasing since the beginning of the 21 st century. While in 2000 there were 55, B\&H itself in 2012, there were 28 banks operating in B\&H, including ten which had their headquarters on the territory of the Republic of Serbia and eighteen banks that were based in B\&H (Agić, 2012, pp. 86-111). In terms of ownership structure, there has not been a significant change - foreign capital engagement increased from $25 \%$ in 2001 to almost $80 \%$ in 2014 .

The level of financial intermediation (i.e. the share of banking assets in GDP), and hence the share of loans and deposits in GDP, indicates a degree of saturation within the banking market. The high ratio of banking assets to GDP (86.8\%) in 2009 in B\&H has increased by 2.3 p.p. up to $89.1 \%$ GDP in 2013. Simultaneously, the share of total loans in GDP rose from $58.1 \%$ up to $62.3 \%$, and the share of total deposits in GDP between 50\% to 54.1\%.

\section{Islamic banking in Bosnia and Herzegovina}

Islamic banking in Bosnia and Herzegovina is in an early stage of its development (Klepic, 2009, p. 4). The first attempt to open a bank working according to Islamic principles was made in early 1990. Had the war not started, the first Islamic bank would have been in the former Yugoslavia, based in Sarajevo.

In 1992, in Sarajevo, Vakufska Bank d.d. was established, which was meant to operate on Islamic financial principles. This attempt failed, as the bank mostly operated on conventional banking principles rather than Sharia principles. The next attempt to form a purely Islamic bank occurred in 1996 when Orient Bank d.d. was opened in Sarajevo. The bank offered non-interest loans and attracted foreign investors to raise the capital. But, because the increasing minimum capital requirements were not satisfied, the bank had to close.

The first and last successful try to launch Islamic banking in Bosnia and Herzegovina was realized in 2000 when Bosna Bank International (BBI) was established in Sarajevo. It was the first bank of its type in Europe and is the only bank in $\mathrm{B} \& \mathrm{H}$ to operate in accordance with Islamic principles. On the one hand, domestic banking law does not respect the attributes of the Islamic interest-free business model, on the other, it is not an obstacle to forming such banks (Ergun, Djefovic, 2011, p. 11). The share capital of this bank amounted to KM 47.52 million, which at that time was the largest amount paid in capital compared to other banks in the country (BBI 2015a). The bank was founded by three significant financial institutions with Islamic roots and with total resources amounting to over 22 billion USD. $45.46 \%$ of shareholders' capital belongs to the Islamic Development Bank and $27.27 \%$ of the capital to each of the following banks: Dubai Islamic Bank and Abu Dhabi Islamic Bank (BBI 2015b). In 2002, the bank received two important documents from the Banking Agency of the Federation of B\&H: a permit to 
perform domestic transactions and a license for deposit insurance. These allow the bank to offer financial services and products both for corporate and retail customers. Bosna Bank International is mostly involved in the long-term financing of acquisitions, constructions, and adaptations of real estate in Bosnia and Herzegovina.

Bosna Bank International is the subject of a few empirical studies. Efendic (2011, pp. 9-10) with the use of the DEA model, analyzed the efficiency of that bank in comparison to a sample of 18 conventional banks operating in $\mathrm{B} \& \mathrm{H}$; he concludes that the Bosnian Islamic bank is less efficient than its conventional counterparts: foreign banks operating in $\mathrm{B} \& \mathrm{H}$ and banks with assets up to a quarter of a billion EUR. Ali Göksu (2012, p. 37) studied customers' attitudes, beliefs and perceptions about the services offered by the Islamic bank in B\&H. The results of the research involving 186 clients suggest differences between conventional banks in B\&H and Bosna Bank International, and highlight the problems with and opportunities for Islamic banking in the country as well as possible suggestions for improvement in this sector. Nuhanović (2014, pp. 37-50) investigates the Islamic banking system as a potential answer to future economic crises because of the specific risk management in interest-free banking. The author draws special attention to this banking sector in $\mathrm{B} \& \mathrm{H}$, focusing on its development and current position within the country's complex economic and social conditions. It has also been suggested that Bosnia will become the center of Balkan Islam for its Muslim institutions; but, it also stands as a symbol of the Islamic world's failure to protect those it regarded as its brethren (Lederer, 1997-1999, pp. 4-12).

\section{Research methodology}

The CAMELS approach was chosen to carry out the comparative analysis of the financial situation of banks in B\&H. It is an early warning system introduced in the US in the 80s (Bauer et al., 1998)based on a group of quantitative and qualitative criteria and makes use of financial indices. These criteria are related to a studied market's capital (Capital), quality of assets (Asset quality), management (Management), profitability (Earnings) and liquidity (Liquidity); the tool was extended to include market risk sensitivity (Sensitivity to market risk), thereby becoming CAMELS (Christopoulos et al., 2011, p.12).

The literature addressing the CAMELS approach is quite rich, starting with the use of the approach to predict bank failures (Barker, Holdsworth, 1993) and to assess financial institutions from a banking sector (Cole, Gunther, 1998, pp. 103-117; Barr et al., 2002, pp. 3 -25). CAMELS has been used in the study of Islamic banking in various countries as well. Sarker (2005, pp. 8-23) proved that thanks to CAMELS the supervisory authority in Bangladesh was able to take advantage of Sharia as a benchmark during the inspection and monitoring of Islamic banks. A study carried out by Jaffar and Manarvi (2011, pp. 60-67) showed that 
Islamic banks achieved a better performance rating in terms of possessing adequate capital and liquidity compared to conventional banks, which had pioneered management quality and earning ability. Kabir and Dey (2012, pp. 16-25) also analyzed the state of private banks in Bangladesh with the use of this tool.

However, this approach has not been used in studies of the banking sectors in the countries of the Western Balkans; therefore, the purpose of this article is to fill this gap in the literature in a few areas: to use the approach to analyze the banking sector in the region of the Western Balkans; and to compare an Islamic bank to the banking sector in a country where the development of Islamic finance seems the most possible. In order to compare the situation of BBI to the banking market in $\mathrm{B} \& \mathrm{H}$ and the region of the Western Balkans (including Croatia, $\mathrm{B} \& \mathrm{H}$, and Macedonia), the following ratios were chosen: Capital Adequacy Ratio, Non-performing Assets to Total Assets, Personnel Expenses to Non-interest Expenses, Return on Assets, Return on Equity, and Short-term Liabilities to Total Assets. The analysis applies to the period of five years between 2010 and 2014, since it was a time of transformation within the banking sector and the country was coping with the financial crisis which affected the local banking sector through indirect channels.

\section{Results of empirical the research}

Table 4 presents the average ratio values for the studied bank and the average values of the banking sector in B\&H within the period of the analysis.

Table 4. Average values of ratios used in the CAMELS approach in the studied countries between 2010-2014

\begin{tabular}{|l|c|c|c|c|c|c|}
\cline { 2 - 7 } \multicolumn{1}{c|}{} & Capital & Asset quality & Managament & \multicolumn{2}{c|}{ Eernings } & Liquidity \\
\cline { 2 - 7 } & CAR & $\begin{array}{c}\text { Non-performing } \\
\text { Assets to Total } \\
\text { Assets }\end{array}$ & $\begin{array}{c}\text { Personnel } \\
\text { Expenses to } \\
\text { Non-interest } \\
\text { Expenses }\end{array}$ & ROA & ROE & $\begin{array}{c}\text { Short-term } \\
\text { Liabilities / } \\
\text { Total Assets }\end{array}$ \\
\hline BH & 16.89 & 9.83 & $\mathrm{n} / \mathrm{a}$ & 0.25 & 1.99 & 0.59 \\
\hline $\begin{array}{l}\text { Balkan } \\
\text { States }\end{array}$ & 17.99 & 11.26 & 37.01 & 0.57 & 4.55 & 0.61 \\
\hline BBI & 18.26 & 10.71 & 31.22 & 0.50 & 3.51 & 0.50 \\
\hline
\end{tabular}

Source: author's own elaboration.

The CAMELS analysis of Bosna Bank International compared to the whole Bosnian banking sector during the period of five years between 2010 and 2014 indicates that the bank's situation was relatively more stable. Although the average capital adequate ratios (CAR) were close, the annual comparison (Figure 2) 
presents a relatively stable situation in the Bosnian sector as a whole as well as in the banking sectors in the Western Balkan region, with an increasing tendency towards greater stability up till 2013. BBI's situation manifests fluctuations. The reason for these changes comes from the $60 \%$ increase in the bank's share capital between 2012 and 2013, accompanied by the changing speed of the growth of Risk-Weighted Assets, between 9\% to $31 \% \mathrm{y} / \mathrm{y}$.

Figure 2. Regulatory Capital to Risk-Weighted Assets in \%

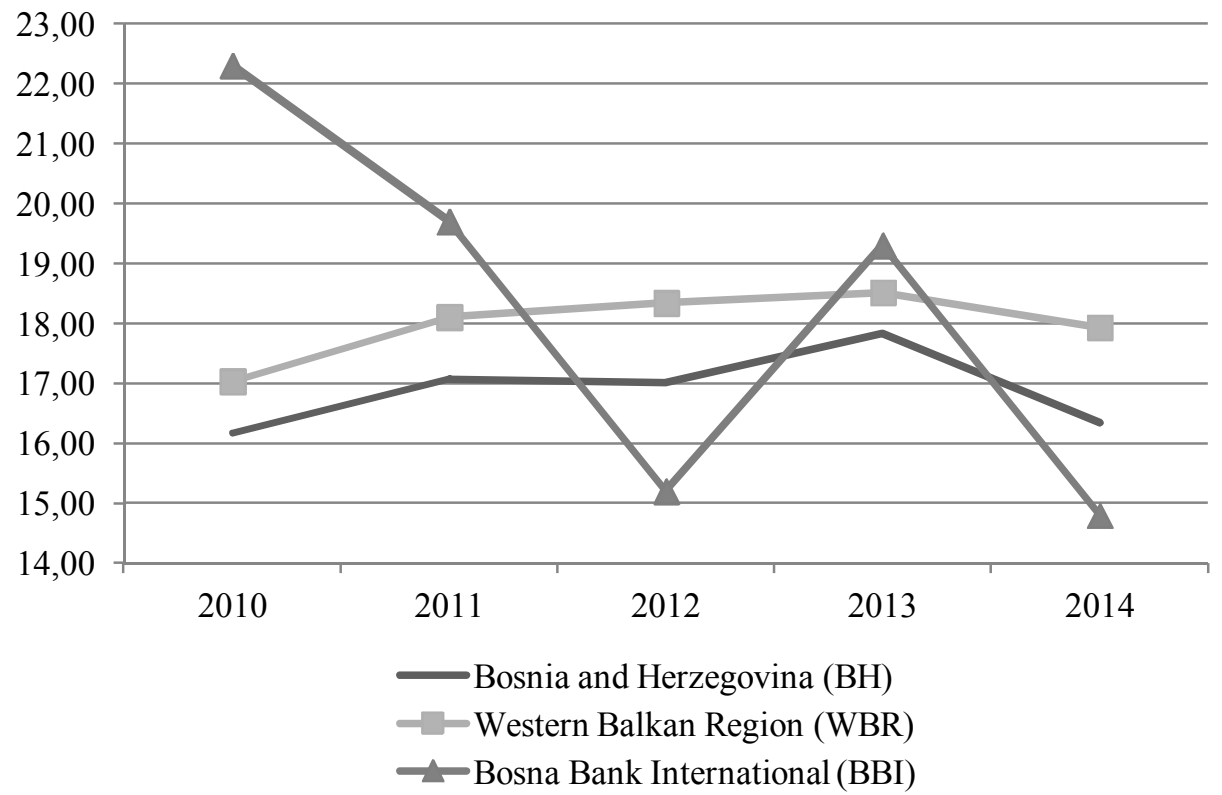

Source: author's own elaboration based on the International Monetary Fund (2015) and the Annual Reports of Bosna Bank International.

As far as the quality of assets is concerned, it has been noted that the ratio of Non-performing Assets to Total Assets (Figure 3) is increasing in the Balkan States, as well as in Bosnia. It must be noted that the ratios in this scope in the region are visibly higher than the Bosnian averages. Although the level of non-performing assets has never exceeded $13 \%$, a significant rising tendency has been noted in this region. The highest ratios were reached in 2014, topping the values of 2010 by over one third. This shows that the economic situation there, as a consequence of the global crisis, was not good and may have affected the banking sectors. The situation in this scope in $\mathrm{B} \& \mathrm{H}$ is little better compared to that of the region as a whole. Not only is the level of ratio lower, but also the speed of the increase is slower. When it comes to BBI, the situation is not as simple as it may be presented. The situation in this field has become relatively 
worse in the Balkan States. On average, the ratio in BBI was better, meaning that it achieved a lower level. But, because non-performing assets in 2012 doubled in comparison to the previous year, the ratio this year increased by close to $16 \%$.

Figure 3. Non-performing Assets to Total Assets in \%

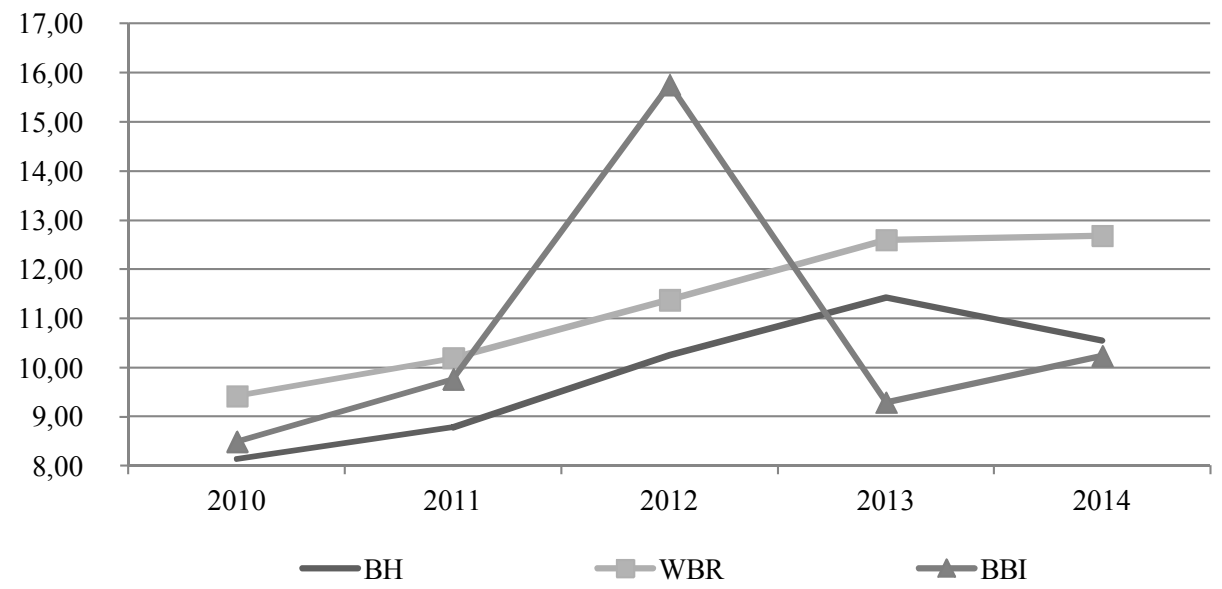

Source: author's own elaboration based on the International Monetary Fund (2015) and the Annual Reports of Bosna Bank International.

Figure 4. Personnel Expenses to Non-interest Expenses in \%

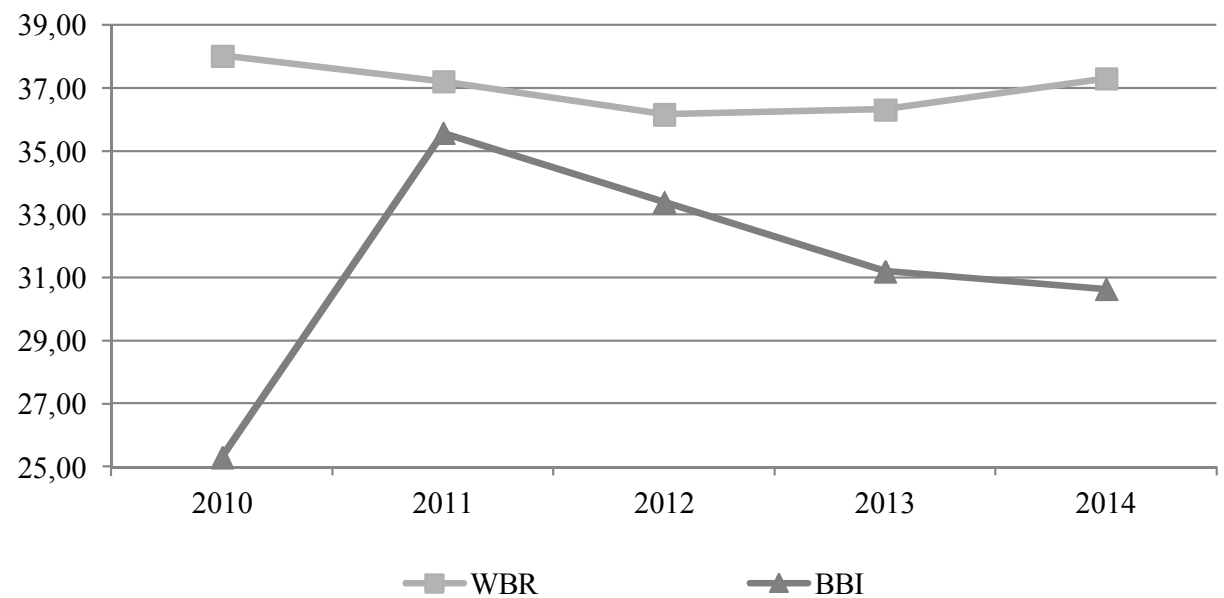

Source: author's own elaboration based on the International Monetary Fund (2015) and the Annual Reports of Bosna Bank International. 
When it comes to management of employees, the ratio of Personnel Expenses to Non-interest Expenses (Figure 4) can be used to demonstrate the quality and skills of the staff working in the sector. The higher the ratio, the more is spent on employees. Comparing the Balkan and the BBI situation, it can be concluded that relatively more (on average, almost 6 p.p. more) is spent on this area in the purely Muslim bank. The difference in 2010 was the most meaningful (almost 13 p.p. more); while later it decreased very significantly.

Liquidity is one of the most important financial objectives, not only of any legal entity but also of banking sectors analyzed as whole markets. The situation of the compared countries in this respect is quiteclear. $\mathrm{B} \& \mathrm{H}$ is characterized by a liquidity that is very comparable to that of the Balkan region (Figure 5). The exception here is BBI, which as a consequence of the Sharia banking model, obtained the least share of short term assets compared to the whole banking sector of $\mathrm{B} \& \mathrm{H}$ as well as banking sectors in the region.

Figure 5. Short term Liabilities to Total Assets in \%

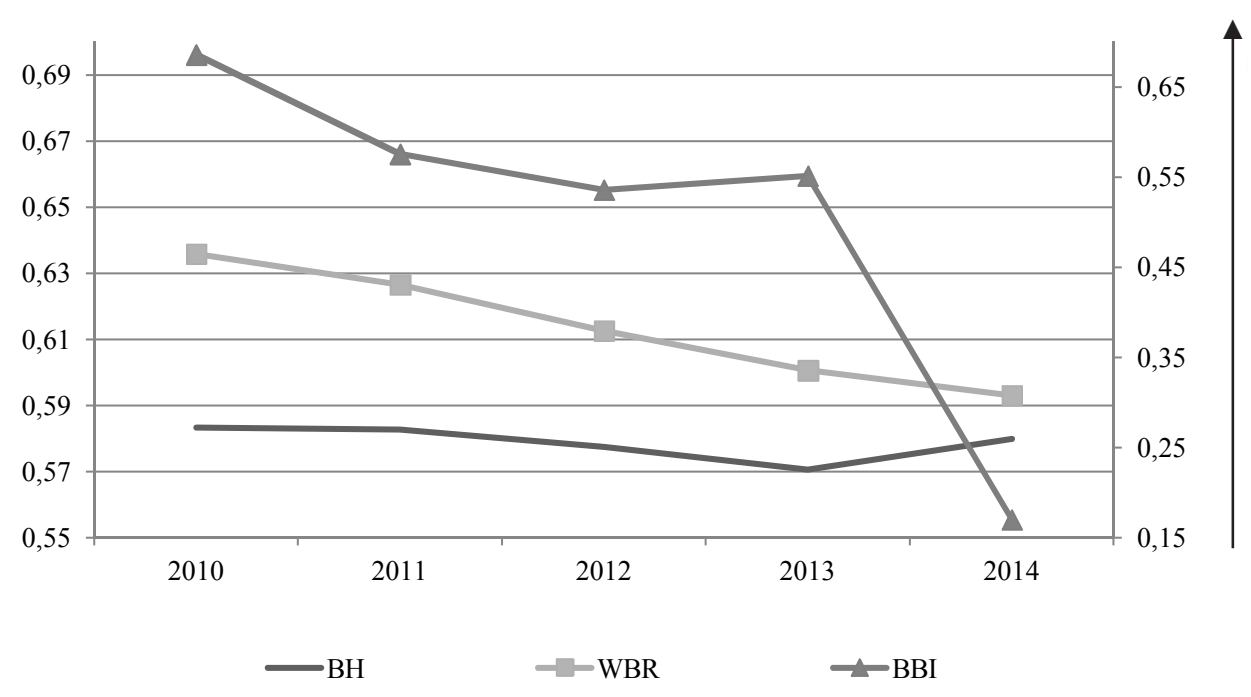

Source: author's own elaboration based on the International Monetary Fund (2015) and the Annual Reports of Bosna Bank International.

(The right axis presents BBI, the left $-\mathrm{BH}$ and WBS).

By comparing the performance of the banking sectors in the studied region, it can be concluded that better achievements characterize the Balkan region as the whole. Return on Equity (ROE) and Return on Assets (ROA) ratios (Figures 6-7) show how efficiently the management transfers sources into effects. Both the ratios achieve significantly higher average values in BBI: an ROE of 3.51\% and an ROA 
of $0.5 \%$, respectively, while in the Bosnian sector it is $1.99 \%$ and $0.25 \%$. It should be mentioned that, compared to the Balkan States, Bosnia suffered the most from the global financial crisis. The performance ratios (ROE, ROA) reached negative values in 2010 and in 2013. They were also significantly lower than in the other countries in the region.

Figure 6. Return on Assets

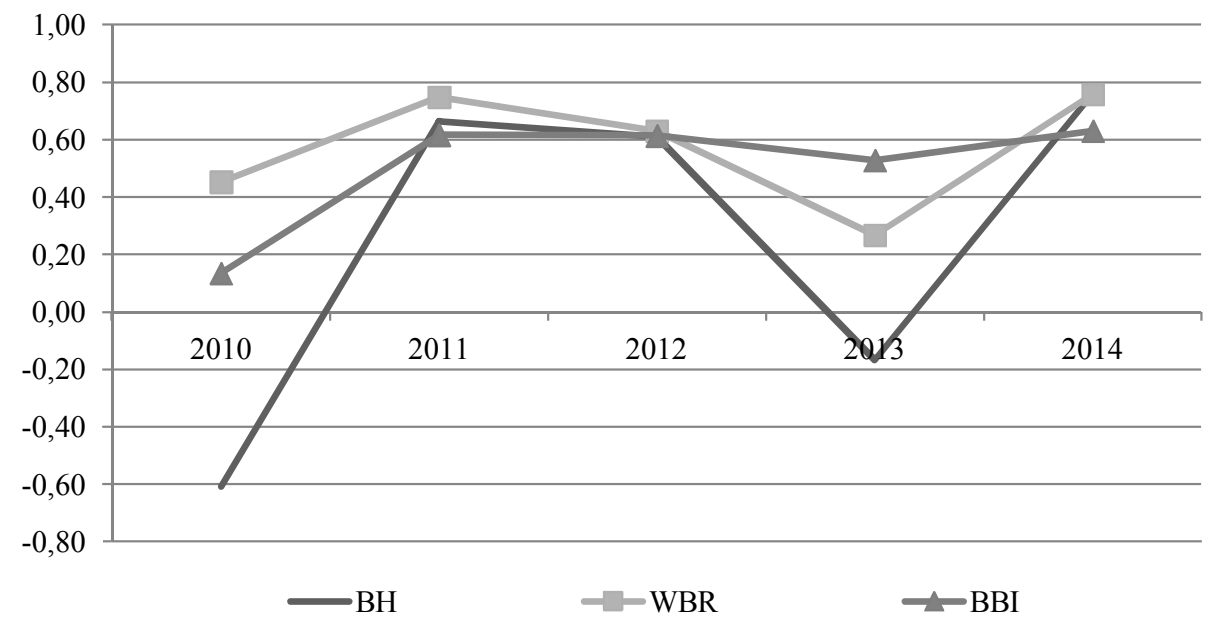

Source: author's own elaboration based on the International Monetary Fund (2015) and the Annual Reports of Bosna Bank International.

Figure 7. Return on Equity

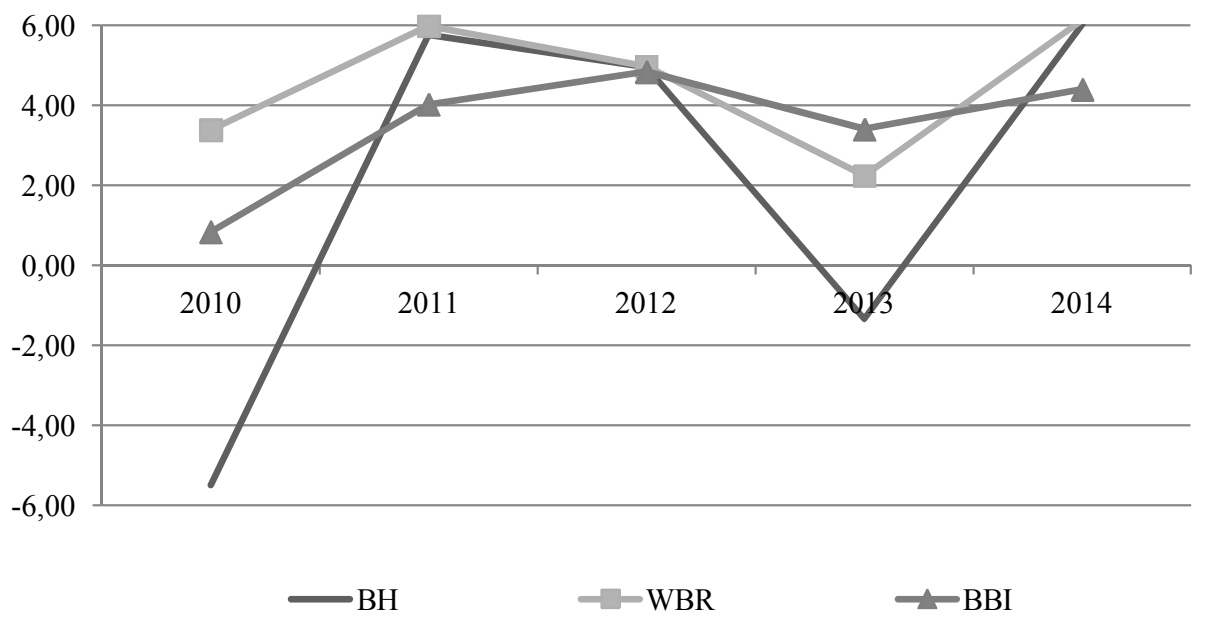

Source: author's own elaboration based on the International Monetary Fund (2015) and the Annual Reports of Bosna Bank International. 


\section{Conclusions}

The importance of Islamic banking in Europe is indisputable. The increasing number of publications addressing the issue suggests the increasing role of this subsector of the banking market. Thanks to the review of the literature presented in the first part of the article, it can be said that there are two points of view related to the significance of both business models: conventional and Islamic. According to the first, there is not much difference between the two; therefore, the comparison in many ways does not answer the question of which model of banking is more beneficial and profitable. The second believes that there is a reasonable amount of difference between them.

The results present comparisons between Bosna Bank International and the local Bosnian sector as well as the banking markets in the Western Balkan region. The CAMELS analysis of Bosna Bank International compared to the whole Bosnian banking sector covering the period of five years between 2010 and 2014 indicates that the bank's financial situation was relatively more stable. The following factors were chosen for the analysis: Capital Adequacy Ratio, Non-performing Loans to Total Loans, Personnel Expenses to Non-interest Expenses, Return on Assets, Return on Equity, and Short-term Liabilities to Total Assets.

\section{Bibliography}

ADIB (2015), ADIB, [Online] Available at: http://www.adib.ae [accessed on: $11 / 11 / 2015]$.

Agić Z. (2012), Comparison of bank success in Bosnia And Herzegovina and countries in the region in 2012. Available at: http://dx.doi.org/10.7251/ akt1321142s.

Alfaro L., Chanda A., Kalemli-Ozcan S., Sayek S. (2003), FDI Spillovers, Financial Markets and Economic Development, IMF Working Paper, Working Paper No. 03/186: pp. 1-33. Available at: http://dx.doi.org/10.5089/97814 51859485.001.

Arestis, P. Panicos, D. (1997), Financial development and economic growth: Assessing the evidence. The Economic Journal 107 (442), pp. 783-799.

Ariss R.T. (2010), Competitive conditions in Islamic and conventional banking: A global perspective, Review of Financial Economics Vol. 19, pp. 101-108. Available at: http://dx.doi.org/10.1016/j.rfe.2010.03.002.

Ashfaq A., Kashif-ur-Rehman, Iqbal Saif M. (2010), Islamic Banking Experience of Pakistan: Comparison between Islamic and Conventional Banks, International Journal of Business and management Vol. 5, No. 2. Available at: http:// dx.doi.org/10.5539/ijbm.v5n2p137. 
Awan A.G. (2009), Comparison of Islamic And Conventional Banking In Pakistan, Proceedings $2^{\text {nd }}$ CBRC, Lahore, Pakistan.

Babic-Hodovic V., Tesche J. (2006), FDI and the Banking Sector in B\&H and the Region, International Management Development Association Proceedings, pp. 1-7.

Babić-Hodović, V., Mehić, E., Agić, E. (2009), Influence of Quantitative and Qualitative Factors of Banking Sector Development on Economic Growth in South East European Countries, Interdisciplinary Management Research, Vol. 5, pp. 683-693.

Barker D., Holdsworth D. (1993), The Causes of Bank Failures in the 1980s. Research Paper No. 9325.

Barr R.S., Killgo K.A., Siems T.S., Zimmel S. (2002), Evaluating the productive efficiency and performance of US commercial banks, Managerial Finance, Vol. 28 Issue: 8, pp. 3-25

Bauer P.W., Berger A.N. (1998), Ferrier G.D., Humphrey D.B. Consistency conditions for regulatory analysis of financial institutions: A comparison of frontier efficiency methods, Journal of Economics and Business, Vol. 50.

BBI (2015a), Bosnia Bank International.About Us, Available at: http://www.bbi. ba/en/static/about-us [accessed on: 11/11/2015].

BBI (2015b), Bosnia Bank International. Bank Founders, Available at: http:// www.bbi.ba/en/static/bank-founders [accessed on: 11/11/2015].

Beck T., Demirgüç-Kunt A., Merrouche O. (2013), Islamic vs. Conventional Banking: Business Model, Efficiency and Stability, Journal of Banking \& Finance Vol. 37 Issue 2, pp. 433-447. Available at: http://dx.doi.org/10.1016/j. jbankfin.2012.09.016.

Beng S.C., Ming-Hua L. (2006), Islamic banking: Interest-free or interest-based?, Pacific-Basin Finance Journal 17, pp. 125-144. Available at: http://dx.doi. org/10.2139/ssrn.868567.

Bley, J.; Kuehn, K. (2004), Conventional Versus Islamic Finance: Student Knowledge and Perception in the United Arab Emirates, International Journal of Islamic Financial Services 5 (4), pp. 17-30.

Bourkhis K., Sami Nabi M. (2013), Islamic and conventional banks'soundness during the 2007-2008 financial crisis, Review of Financial Economics Vol. 22, Issue 2, pp. 68-77. Available at: http://dx.doi.org/10.1016/j.rfe.2013.01.001.

Cargill, T. F. (1989), CAMEL Ratings and the CD Market,Journal of Financial Services Research 3 (4), pp. 347-358.

Casu B., Girardone C., Molyneux P. (2006), Introduction to Banking, Prentice Hall, FT, England: Pearsons Education.

CBBH Annual Report (2010), Central Bank of Bosnia and Herzegovina, Annual Report.

Cevik S., Charap J. (2011), The Behavior of Conventional and Islamic Bank Deposit Returns in Malaysia and Turkey, IMF Working Paper WP/11/156. Available at: http://dx.doi.org/10.5089/9781455293704.001. 
Chapra U.M. (1992), Islam and the Economic Challenge, Leicester, UK: The Islamic Foundation.

Chong B.S., Liu M.H. (2009), Islamic banking: Interest-free or interest-based?, Pacific-Basin Finance Journal, No. 17.

Cole R.A., Gunther J. (1998), Predicting Bank Failures, A Comparison of On-And Off-Site Monitoring Systems, Journal of Financial Services Research, 13(2).

Christopoulos A., Mylonakis J., Diktapanidis P. (2011), Could Lehman Brothers ' Collapse Be Anticipated? An Examination Using CAMELS Rating System, International Business Research, Vol. 4, No. 2, pp. 11-19.

Dubai Islamic Bank, 2015. Dubai Islamic Bank. [online] Available at: http://dib.ae/ [accessed on: 11/11/2015].

Efendić V. (2011), Efficiency of the Banking Sector Of Bosnia-Herzegovina with Special Reference to Relative Efficiency of the Existing Islamic Bank, 8th International Conference on Islamic Economics and Finance, Doha - Qatar, 18th - 20th December 2011.

Ergun U., Djedovic I. (2011), Islamic Banking with a Closer Look at Bosnia and Herzegovina: Knowledge, Perceptions and Decisive Factors for Choosing Islamic Banking, 8th International Conference on Islamic Economics and Finance, Doha - Qatar, 18th - 20th December 2011.

Göksu A., Becic A. (2012), Awareness of Islamic Banking in Bosnia and Herzegovina, International Research Journal of Finance and Economics, Issue 100, pp. 26-39.

Hamid M.A., Azmi S.M. (2011), The Performance Of Banking During 20002009: Bank Islam Malaysia Berhad And Conventional Banking In Malaysia, International Journal of Economics and Management Sciences Vol. 1, No. 1, pp. 09-19.

Hasan M., Dridi J. (2010), The Effects of the Global Crisis on Islamic and Conventional Banks: A Comparative Study, IMF WP/10/2010. Available at: http://dx.doi.org/10.5089/9781455205318.001

IFN Islamic Finance News (2014), IFN Country Analysis - Bosnia. [Online] Available at: www.islamicfinancenews.com/ifn-country-analysis-bosnia?page $=1$ [accessed on: 8/10/2014].

Ika S.R., Norhayati A. (2011), A Comparative Study Of Financial Performance Of Islamic Banks And Conventional Banks In Indonesia, International Journal of Business and Social Science Vol. 2, No. 15, pp. 199-2017.

International Monetary Fund (2015), IMD eLibrary Data, [online] Available at: http://elibrary-data.imf.org/ [accessed on: 11/11/2015].

Islamic Development Bank (2015), Islamic Development Bank, [online] Available at: http://www.isdb.org [accessed on: 11/11/2015].

Iquibal Z. (1997) Islamic Financial Systems, Finance \& Development, pp. 42-45, https://www.imf.org/external/pubs/ft/fandd/1997/06/pdf/iqbal.pdf.

Iqbal M. (2001), Islamic And Conventional Banking In The Nineties: A Comparative Study, Islamic Economic Studies Vol. 8, No. 2. 
Jaffar M., Manarvi I. (2011), Performance comparison of Islamic and Conventional banks in Pakistan, Global Journal of Management And Business Research Vol. 11, Issue 1.

Johnes J., Izzeldin M., Pappas V. (2014), A comparison of performance of Islamic and conventional banks 2004-2009, Journal of Economic Behavior \& Organization 103, pp. S93-S107. Available at:http://dx.doi.org/10.2139/ ssrn.2071615.

Kabir A., Dey S. (2012) Performance Analysis through CAMEL Rating: A Comparative Study of Selected Private Commercial Banks in Bangladesh, Journal of Politics \& Governance Vol. 1, No. 2/3.

Kearney A.T., Korea LLC (2012), The Future of Islamic Banking, Seoul: A.T. Kearney, Inc.

Khan M., Mirakhor A., (1989), The Financial System and Monetary Policy in an Islamic Economy, Journal of King Abdulaziz University: Islamic Economics, Vol. 1, pp. 39--57. Available at: http://dx.doi.org/10.4197/islec.1-1.2.

Klepić D. (2009), Islamic Banking - Bosnia and Herzegovina, Trade and Investment Officer, British Embassy Sarajevo.

Komorowski, R., Kubiszewska, K., (2014), The UK's banking system as financial hub for Islamic banking, International Journal of Behavioural Accounting and Finance 4(3), pp. 245-258.

Lederer G., Contemporary Islam In East Europe, NATO Research Fellowships Programme,1997-1999 (1999), Camberley: Conflict Studies Research Centre Available at: http://www.nato.int/acad/fellow/97-99/lederer.pdf.

Manshor Amat Taap Siong Choy Chong Mukesh Kumar Tat Kee Fong, (2011), Measuring service quality of conventional and Islamic banks: a comparative analysis, International Journal of Quality \& Reliability Management, Vol. 28, Issue 8, pp. 822-840. Available at: http://dx.doi.org/10.1108/02656711111162505

Mills P.S., Presley J.R. (1999), Islamic finance: Theory and practice, Macmillan, London.

Mohamad S., Taufiq H., Bader M.K.I. (2014), Efficiency of Conventional versus Islamic Banks: International Evidence using the Stochastic Frontier Approach (SFA), Journal of Islamic Economics, Banking and Finance, pp. $107-130$.

Moin M.S. (2008), Performance of Islamic Banking and Conventional Banking in Pakistan: A Comparative Study, University of Skovde, http://his.diva-portal. org/smash/get/diva2:113713/FULLTEXT01.

Nuhanović A. (2014), Specific Risk Management Islamic Banking With Special Reference To Bosnia And Herzegovina, Journal of Applied Economics and Business, Vol. 2, Issue 2, pp. 39-50.

Observatory of Economic Complexity (2015), Observatory of Economic Complexity, [online] Available at: http://atlas.media.mit.edu/en/ [accessed on: 8/11/2015]. 
Olson D., Taisier A. Zoubi (2008), Using accounting ratios to distinguish between Islamic and conventional banks in the GCC region, The International Journal of Accounting, Vol. 43 Issue 1, pp. 45-65. Available at: http://dx.doi. org/10.1016/j.intacc.2008.01.003.

Safiullah Md. (2010), Superiority of Conventional Banks \& Islamic Banks of Bangladesh: A Comparative Study, International Journal of Economics and Finance Vol. 2, No. 3. Available at: http://dx.doi.org/10.5539/ijef.v2n3p199.

Sarker A. (2005), CAMEL Rating System in the Context of Islamic Banking: A Proposed 'S'for Shariah Framework, Journal of Islamic Economics and Finance, Vol. 1, No.1, 2005.

Shamsher M., Taufiq H., Bader M.K. (2007), Efficiency of Conventional versus Islamic Banks: International Evidence using the Stochastic Frontier Approach $(S F A)$, Journal of Islamic Economics, Banking and Finance.

Siti R.I., Norhayati A. (2011), A Comparative Study Of Financial Performance Of Islamic Banks And Conventional Banks In Indonesia, International Journal of Business and Social Science Vol. 2, No. 15.

Sudin Haron, Wan Nursofiza Wan Azmi (2008), Determinants of Islamic and conventional deposits in the Malaysian banking system, Managerial Finance, Vol. 34, Issue 9 pp. 618 - 643. Available at: http://dx.doi.org/10.1108/030743 50810890976.

The World Bank (2015), The World Date Bank's Databank, [online] Available at: http://data.worldbank.org/country/bosnia-and-herzegovina [accessed on: 8/11/2015].

Thomson Reuters Zawya (2015), Thomson Reuters Zawya, [online] Available at: https://www.zawya.com/islamic-finance/ [accessed on: 8/11/2015].

Torbat, A. E. (2005). Impacts of the US trade and financial sanctions on Iran, The World Economy 28 (3), pp. 407-434.

Trading Economics (2015), Trading Economics, [online] Available at: http:// www.tradingeconomics.com/ [accessed on: 811 2015].

UK Trade \& Investment (2014), UK Excellence in Islamic Finance, London: Business is Great Britain.

Usman A., Khan M.K. (2012),Evaluating the Financial Performance of Islamic and Conventional Banks of Pakistan: A Comparative Analysis, International Journal of Business and Social Science, Vol. 3, No. 7.

Warde, I. (2000), Islamic finance in the global economy, Edinburgh: University Press.

Zulkifli, H. (2010), Islamic banking and finance in Bosnia and Herzegovina, [online] Available at: https://zulkiflihasan.wordpress.com/2010/09/29/islamicbanking-and-finance-in-bosnia-and-herzegovina/ [accessed on: 8/11/2015]. 


\section{Summary}

This paper examines the phenomenon of Islamic banking in Bosnia and Herzegovina. Although almost half of the Bosnian population is recognized as Islamic, there is only one bank purely based on Sharia operating in this country. The aim of the article is to conduct a comparative analysis of the financial standing of this bank and the banking sector in this country and region. The chosen method of analysis is CAMELS, which examines an institution by taking into consideration its most crucial elements: capital, assets, management, earnings, liquidity and sensitivity to risk.

Keywords: Islamic Banking, CAMEL, Bosnia and Herzegovina

\section{Streszczenie}

Ocena bankowości islamskiej w Bośni i Hercegowinie - analiza porównawcza z użyciem podejścia CAMELS

W artykule przeprowadzono analizę bankowości islamskiej w Bośni i Hercegowinie. Wprawdzie aż prawie połowa ludności bośniackiej jest pochodzenia islamskiego, to tylko jeden bank funkcjonujący w tym kraju oparł swoją działalność wyłącznie na Szariacie. Celem artykułu jest przeprowadzenie analizy porównawczej sytuacji finansowej tego banku i sektora bankowego zarówno w Bośni, jak i w regionie Bałkanów Zachodnich. Wybrano metodę analizy opartą o system CAMELS, który bada instytucję, biorąc pod uwagę jej najistotniejsze elementy: jakość kapitału, jakość aktywów, zarządzanie w odniesieniu do pracowników, zyskowność, płynność oraz wrażliwość na ryzyko.

Słowa kluczowe: bankowość islamska, CAMELS, Bośnia i Hercegowina JEL: G20, G21 